\title{
Design of dendrimeric structures to treat allergic disorders
}

\author{
AB Blazquez ${ }^{1 *}$, A Aranda ${ }^{1}$, A Mascaraque ${ }^{2}$, MJ Torres $^{3}$, C Mayorga $^{1}$, J Rojo ${ }^{2}$, M Blanca $^{3}$ \\ From Food Allergy and Anaphylaxis Meeting (FAAM 2013) \\ Nice, France. 7-9 February 2013
}

\section{Background}

Polymers containing immunogenic peptides bonded to dendrimeric structures have been developed to be used for vaccines in cancer, infectious diseases, and allergy. Our aim is to design a dendrimeric structure containing Ole e 1 and $\mathrm{CpG}$, in order to modulate an allergic immune response towards Th1, in an experimental model of anaphylaxis.

\section{Methods}

C56BL/6 mice were sensitized by intranasal administration of olive extract+cholera toxin B, for 6 weeks. Then, mice received immunotherapy (IT) treatment by subcutaneous (sc) injection of dendrimer-Ole $1 \pm 50 \mathrm{mg}$ of $\mathrm{CpG}$, for 8 weeks. Seven days after the IT, mice were challenged with $100 \mathrm{mg}$ of olive extract (ip). Severity of anaphylaxis was measured by drop in body temperature and the humoral response by ELISA.

\section{Results}

Olive sensitized mice treated with the dendrimer-Ole1 without $\mathrm{CpG}$ developed a drop in body temperature similar to anaphylactic mice $(35.02 \pm 1.39$ vs $34.48 \pm 0.82$, respectively), indicating that Ole e 1 within a dendrimeric structure is recognized in vivo. On the other hand, 8 weeks after immunotherapy, mice receiving the dendrimer-Ole $1+\mathrm{CpG}$ were significantly protected from the development of systemic anaphylaxis $(37.18 \pm 1.58$ vs $34.48 \pm 0.82, \mathrm{p}<0.05$, respectively). IgE and IgG2a levels decreased after 1-2 weeks of treatment and remained stable over the time; however IgG1 levels were normal.
'Research Laboratory, IMABIS Foundation-Carlos Haya Hospital/Bionand, Malaga, Spain

Full list of author information is available at the end of the article

\section{Conclusion}

Our results indicate that the dendrimer-Ole1 is recognized in vivo. Furthermore, we show that sc administration of dendrimer-Ole $1+\mathrm{CpG}$ protects sensitized mice from the onset of anaphylaxis, and the decrease in IgE levels during the IT treatment may be responsible from that protection.

\section{Disclosure of interest}

None declared.

\section{Author details}

${ }^{1}$ Research Laboratory, IMABIS Foundation-Carlos Haya Hospital/Bionand, Malaga, Spain. ${ }^{2}$ Glycosystems Laboratory, Instituto de Investigaciones Químicas, CSIC, Seville, Spain. ${ }^{3}$ Allergy Service, Carlos Haya Hospital, Malaga, Spain.

Published: 25 July 2013

\section{doi:10.1186/2045-7022-3-S3-P81}

Cite this article as: Blazquez et al:: Design of dendrimeric structures to treat allergic disorders. Clinical and Translational Allergy 2013 3(Suppl 3): P81.
Submit your next manuscript to BioMed Central and take full advantage of:

- Convenient online submission

- Thorough peer review

- No space constraints or color figure charges

- Immediate publication on acceptance

- Inclusion in PubMed, CAS, Scopus and Google Scholar

- Research which is freely available for redistribution
() Biomed Central

\section{Biomed Central}

